\title{
SKIRTINGO AMŽIAUS MOTERŲ PUSIAUSVYROS KAITOS KOMPLEKSIŠKUMO VERTINIMAS NETIESINĖS DINAMIKOS METODAIS
}

\author{
Vida Janina Česnaitienė, Kazimieras Pukėnas, Albertas Skurvydas, \\ Dalia Mickevičienė, Tomas Juraitis \\ Lietuvos kūno kultūros akademija, Kaunas, Lietuva
}

\begin{abstract}
Vida Janina Česnaitienė. Visuomenès sveikatos mokslų magistrè. Lietuvos kūno kultūros akademijos Tęstinių studijų centro metodininkẻ, biologijos mokslų krypties doktorantė. Mokslinių tyrimų kryptis - senėjimo ir raumenų nuovargio poveikis judesių kintamumui ir stabilumui.
\end{abstract}

\section{SANTRAUKA}

Bègant metams ir dèl ligu sutrinka ¿̨vairiu žmogaus fiziologiniu sistemu prisitaikymo gebejjimai, mažèja stabilumas. Visgi žmogaus organizme kur kas daugiau raumenu masès, neuroniniu schemu ir hormonu atsargu, nei reikia išgyvenimui. Šios fiziologinès atsargos leidžia išlaikyti pusiausvyra senstant ir ligu metu (Lipsitz, 2004). Pusiausvyros, vienos iš fiziologiniu sistemu, sutrikimas nustatomas tiriamuosius testuojant funkciniais testais arba instrumentiniais pusiausvyros tyrimo metodais (Juodžbaliené, 2006). Vienas dažniausiu pusiausvyros vertinimo büdu - statine posturografija. Pusiausvyros svyravimu kaita vertinant netiesinès dinamikos metodais galima nustatyti ju kompleksiškuma (Pincus, 1991).

Tyrimo tikslas - išsiaiškinti, kaip amžius veikia pusiausvyros sistema taikant netiesinès dinamikos metodus kūno slègio centro (SC) svyravimu kompleksiškumui apibüdinti. Tikslui pasiekti instrumentiniu pusiausvyros tyrimo büdu (posturografijos metodu) buvo tirtos 45 triju skirtingo amžiaus (amžiaus vidurkis: 24,5 \pm 5,5; 44,5 \pm 3,5; 72,5 \pm 7,5 m.) grupiu moterys. Tiriamosioms ramiai stovint ant jègos plokštès, buvo registruojami kūno slègio centro (SC) svyravimai i šonus ir pirmyn—atgal kryptimis. Küno slègio centro svyravimu trajektorijos kompleksiškumas vertintas skaičiuojant du dydžius - imties entropija (SampEn) ir spektro galios tankio priklausomumq nuo dažnio (SpectrSl).

Rezultatai parodè, kad bėgant metams kūno svyravimu amplitudè ramiai stovint didejja. Vyresnio amžiaus tiriamuju svyravimu $i$ šonus ir pirmyn—atgal amplitude statistiškai patikimai didesne $(p<0,05)$ nei jaunesnio amžiaus respondenčiu. Vertinant pusiausvyros sistemos elgsenos kompleksiškumq nustatyta, kad vyresnio amžiaus tiriamuju SC svyravimu $\dot{i}$ šonus SampEn reikšme statistiškai reikšmingai mažesnė $(p<0,01)$ nei jaunesnio amžiaus tiriamuju. SC svyravimu pirmyn—atgal kryptimi SampEn reikšmé vyresnio amžiaus tiriamuju statistiškai reikšmingai mažesne $(p<0,01)$ nei vidutinio ir jaunesnio amžiaus tiriamuju. Nustatyta, kad vyresnio amžiaus tiriamuju SC svyravimu pirmyn—atgal SpectrSl reikšmé statistiškai reikšmingai didesne $(p \leq 0,05)$ nei jaunesnio ir vidutinio amžiaus tiriamuju.

Didèjant amžiui, ramiai stovint kūno slègio centro svyravimu trajektorijos kompleksiškumas mažeja, t. y. svyravimai reguliarèja ir lètèja. Taikant netiesinès dinamikos metodus galima įvairiapusiškiau ištirti žmoniu motoriniu sistemu funkciju kaita.

Raktažodžiai: amžius, pusiausvyra, reguliarumas, kompleksiškumas.

\section{IVADAS}

$\mathrm{V}$ yresnio amžiaus žmonès prasčiau kontroliuoja raumenų susitraukimo jègą ir laiką, padidejja galūnių judesių trajektorijos, sumažèja judesių tikslumas, dèl to sutrinka pusiausvyra (Schultz, 1992; Enoka, 2003). Dauguma tyrèjų žmonių pusiausvyros būklei nustatyti naudoja statinès posturografijos metodą — registruojamas tiriamojo slègio centro ir atramos reakcijos jègos vektoriaus pradžios taško (SC) koordinačiu pokytis. Rezultatai leidžia nustatyti tiriamojo
SC svyravimus šonine, pirmyn — atgal kryptimis, bendrą svyravimų trajektorijos ilgi, svyravimų greitị ir kitus dydžius, kurie apibūdina tiriamojo pusiausvyros būklę. Bègant metams ir dèl įvairių susirgimų žmogaus fiziologinių funkcijų veikla reguliarejja, darosi periodiška, mažèja jos kompleksiškumas (Lipsitz, 2004). Šiems rodikliams vertinti naudojami tiesiniai ir netiesinès dinamikos metodai (Pincus, 1991). Vienas pagrindinių ir dažniausių dinaminès sistemos kompleksiškumo 
nustatymo būdų yra apytikslès entropijos matavimas, dažnai naudojamas nagrinėjant kūno slègio centro svyravimų trajektorijos kompleksiškumą (Sabatini, 2000; Cavanaugh et al., 2007). Tikslesnị būdą — imties entropijos matavimą (SampEn) dinaminès sistemos kompleksiškumui nustatyti pasiūlè J. S. Richman ir J. R. Moorman (2000). Tiesinių metodų procesui apibūdinti daugiausia taikoma spektrinè analizè. Analizuojant kūno slègio centro svyravimų trajektorijos registruojamu signalų spektrą naudojamas spektro galios priklausomumo nuo dažnio rodiklis SpectrSl. Nagrinèdami mokslinę literatūrą aptikome darbų, kurių metu lyginamas įvairaus amžiaus sveikų ir sergančių žmonių pusiausvyros kompleksiškumas naudojant Sample Entropy (Donker et al., 2007) arba Spectral Slope (Vaillancourt, Newell, 2003; Hong et al., 2006) dydžius. Neaptikome tyrimu, kuriu metu būtų vertintas skirtingo amžiaus moteru pusiausvyros sistemos elgsenos kompleksiškumas naudojant šiuos abu dydžius.

Tyrimo tikslas - ištirti amžiaus poveiki pusiausvyros kaitos kompleksiškumui.

\section{TYRIMO METODAI IR ORGANIZAVIMAS}

Tiriamosios - skirtingo amžiaus (24,5 $\pm 5,5$; $44,5 \pm 3,5 ; 72,5 \pm 7,5$ m.) moterys $(n=45)$. Lentelëje pateikti tiriamuju amžiaus, kūno masès indekso rodikliai. Tiriamosios buvo supažindintos su tyrimo tikslais, protokolu. Tyrimo protokolas aptartas ir patvirtintas Kauno regioniniame biomedicininių tyrimų etikos komitete.

Pusiausvyros vertinimas. Tiriamujų pusiausvyra buvo vertinama statinès posturografijos metodu. Tuo tikslu naudota jègos plokštė KISTLER (Slimline System 9286, Šveicarija), skirta žmogaus biomechaninèms ypatybėms tirti.

Tyrimo organizavimas. Kiekviena tiriamoji atmerktomis akimis, žvilgsni nukreipusi tiesiai prieš save, pėdas pastačiusi vieną šalia kitos, rankas nuleidusi prie šonų, delnus pasukusi ị vidų 60 s stovejjo ant jėgos plokštės. Posturogramos registravimo trukmè - $60 \mathrm{~s}$, registruojamo signalo diskretizavimo periodas - $10 \mathrm{~ms}$. Registravome SC koordinačių kitimo kreives šonine (SCdx) ir pirmyn-atgal (Scdy) kryptimis. Posturograma buvo pradedama registruoti tiriamosioms taisyklingai atistojus ant jègos plokštės. Vertinant tiriamujų pusiausvyrą apskaičiuotas:

SCdx — SC koordinačių kitimas šonine kryptimi (mm / s);

SCdy - SC koordinačių kitimas pirmyn—atgal kryptimi (mm / s).

1 paveiksle pavaizduotas n-osios tiriamosios posturogramos registravimo kreivès pavyzdys.

Pusiausvyros kompleksiškumo vertinimas. Pusiausvyros kaitos kompleksiškumas apskaičiuotas pagal J. S. Richmann, J. R. Moorman metodiką (Richmann, Moorman, 2000). Slègio centro koordinačių kitimams šonine ir pirmynatgal kryptimis îvertinti buvo apskaičiuoti du dydžiai - imties entropija SampEn (SampEn)
1 pav. Slègio centro koordinačių kitimo kreivė pirmyn-atgal kryptimi (Scdy)

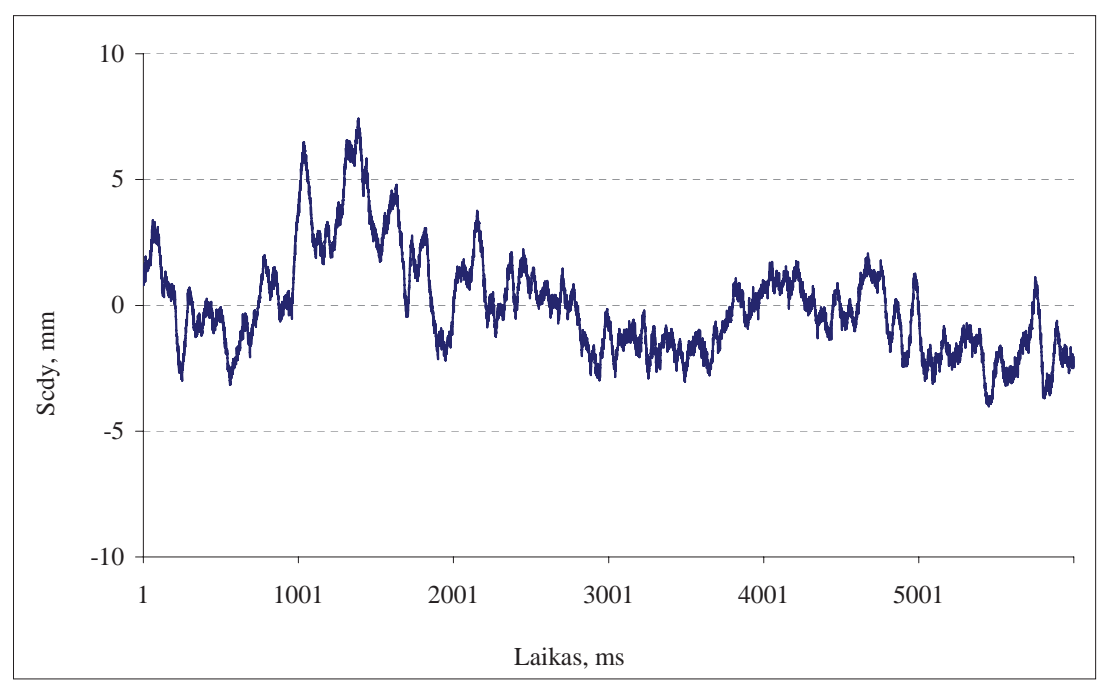

Lentelè. Tiriamųjų amžiaus ir kūno masès indekso rodikliai $(\overline{\mathbf{x}} \pm \mathrm{S})$

Pastaba. ( $\overline{\mathrm{X}} \pm \mathrm{S}$ ) - aritmetinis vidurkis \pm standartinis nuokrypis.

\begin{tabular}{|c|c|c|c|}
\hline $\begin{array}{ll}\text { Grupès } & \text { Rodikliai } \\
\end{array}$ & Skaičius & Amžius, m. & $\begin{array}{c}\text { Kūno masès indeksas, } \\
\mathrm{kg} / \mathrm{m}^{2}\end{array}$ \\
\hline 1 & 15 & $24,5 \pm 5,5$ & $20,4 \pm 2,4$ \\
\hline 2 & 15 & $44,5 \pm 3,5$ & $25,4 \pm 3,9$ \\
\hline 3 & 15 & $72,5 \pm 7,5$ & $25,5 \pm 2,9$ \\
\hline
\end{tabular}


ir SpectrSl. SampEn apskaičiavome pagal formulę:

$$
\text { Samp En }(m, r, N)=-\ln (A / B),(1)
$$

čia B — bendras $m$ ilgio sekų sutapimų ( $r$ tikslumu) skaičius $N$ ilgio eilutèje; $A-$ bendras $m+1$ ilgio sekų sutapimu ( $r$ tikslumu) skaičius $N$ ilgio eiluteje; $A$ / B reiškia sąlygišką tikimybę, kad dvi eilutès, $r$ tikslumu sutampančios $m$ atkarpoje, $r$ tikslumu sutaps ir $m+1$ atkarpoje.

Imties entropija apibūdina laiko eilutès reguliarumą:

- kai SampEn $\rightarrow 0$, procesas reguliarus;

- kai SampEn $\geq 2$, procesas stochastinis.

SpectrSl nusako spektro galios (tankio) priklausomumą nuo dažnio ir apskaičiuojama pagal formulę (Vaillancourt, Newell, 2003):

$$
S=a \times f^{b}
$$

čia $S$ - spektro galios tankis, $f$ - dažnis, $b$ - koeficientas, nusakantis spektro galios tankio priklausomumą nuo dažnio. Koeficientui apskaičiuoti lygtis logaritmuojama, tada $b$ gaunamas kaip tiesès $\ln (S)=\ln (a)+b \times \ln (f)$ polinkio laipsnis.

Absoliučiu dydžiu mažesnès SpectrSl reikšmès rodo tiriamojo signalo savybes ir aukštesnių daž- nių svarba, o didesnès (absoliučiu dydžiu) SpectrSl reikšmès - tiriamojo signalo dažnių koncentracija žemesnių dažnių spektre.

Amžiaus poveikis šiems dviems dydžiams buvo vertinamas vieno veiksnio dispersinès analizès metodu (SPSS 13 versija). Skirtumo reikšmingumas tarp grupių rodiklių buvo tikrinamas Tukey Post Hoc testu.

\section{REZULTATAI}

Tyrimo rezultatai parodè, kad bėgant metams didèja SCdx ir SCdy amplitudè (2 ir 3 pav.). Nustatyta, kad trečios grupès tiriamujų vidutinès SCdx (5,84 mm / s) ir SCdy $(8,97 \mathrm{~mm} / \mathrm{s})$ reikšmès statistiškai reikšmingai $(\mathrm{p}<0,05)$ didesnès nei pirmos grupès tiriamuju (SCdx $-4,72 \mathrm{~mm} / \mathrm{s}$ ir SCdy - 7,33 mm / s). Antros grupès tiriamuju SCdy vidutinè reikšmė $(8,52 \mathrm{~mm} / \mathrm{s})$ statistiškai reikšmingai $(\mathrm{p}<0,05)$ didesnè nei pirmos grupès SCdy tiriamuju (7,33 mm / s).

Didėjant amžiui mažèja SCdx ir SCdy svyravimai SampEn (4 pav.). Trečios grupès tiriamuju SCdx svyravimų SampEn vidutinė reikšmė $(0,28)$
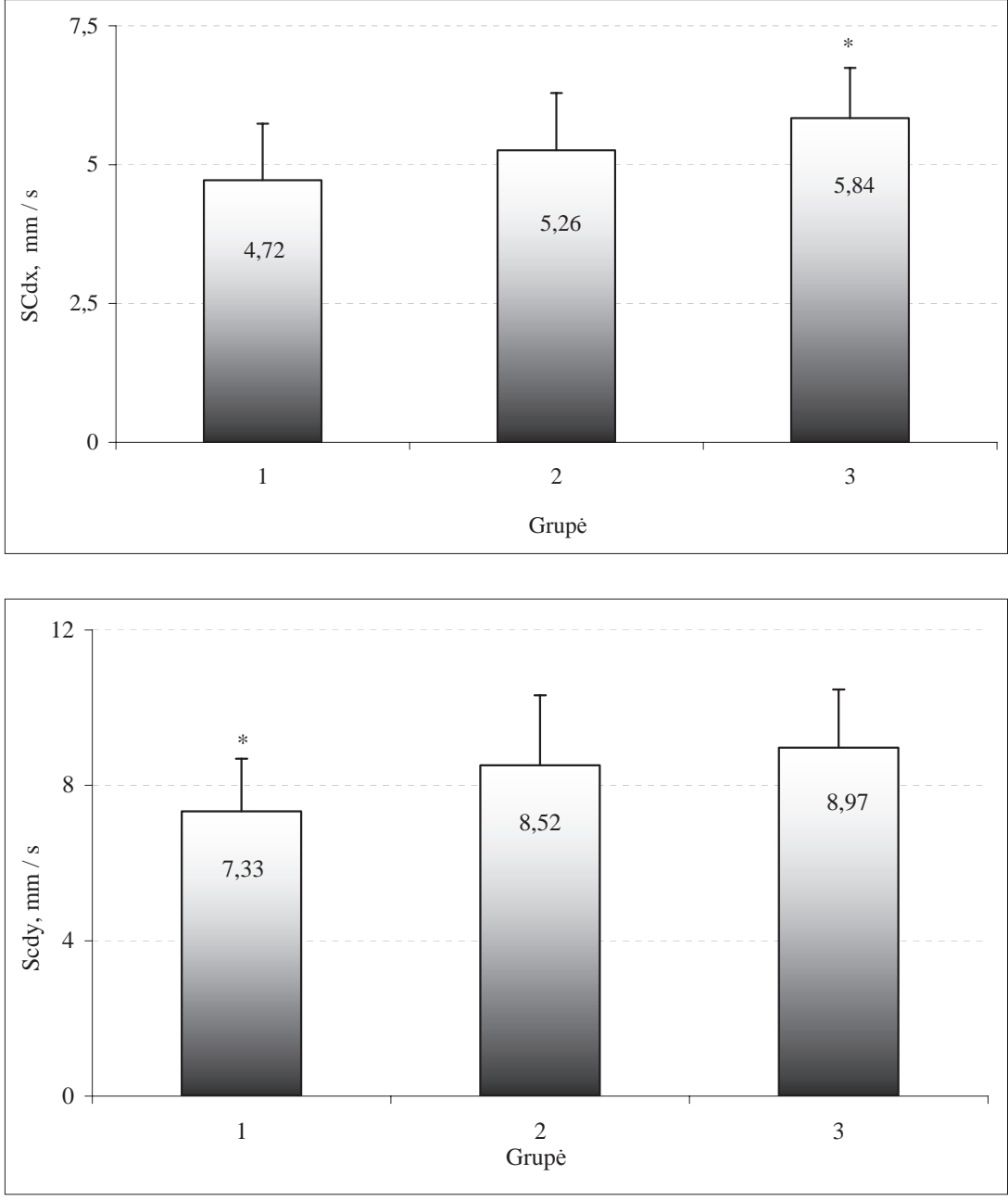

2 pav. Slėgio centro koordinačiu kitimo šonine kryptimi (SCdx) vidutinès reikšmès

Pastaba. * - p $<0,05$, lyginant su 1 grupés rodikliais.

3 pav. Slègio centro koordinačių kitimo pirmyn-atgal kryptimi (Scdy) vidutinès reikšmès

Pastaba. * - p $<0,05$, lyginant su 2 ir 3 grupés rodikliais. 
4 pav. Imties entropijos (SampEn) vidutinès reikšmès

Pastaba. * $-\mathrm{p}<0,01$, lyginant su 1 grupès, \#- $\mathrm{p}<0,01$, lyginant su 1 ir 2 grupès rodikliais.

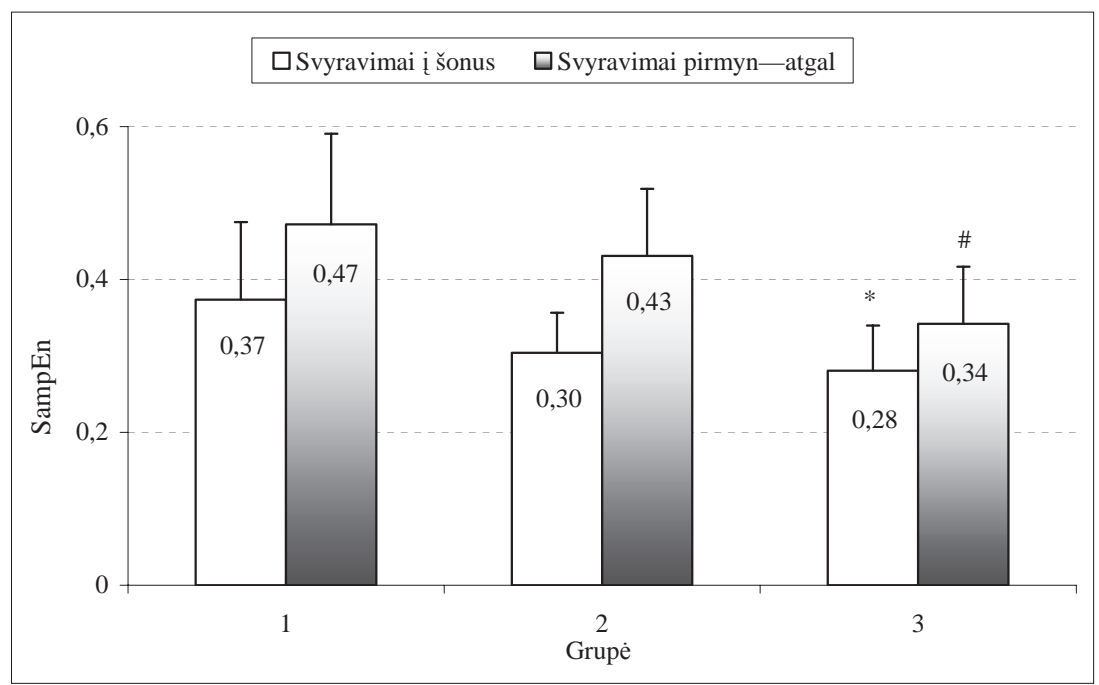

5 pav. Spektro galios tankio priklausomumas nuo dažnio rodiklio (SpectrSI) vidutinès reikšmès

Pastaba. $*-p<0,05$, lyginant su 1 ir 2 grupès rodikliais.

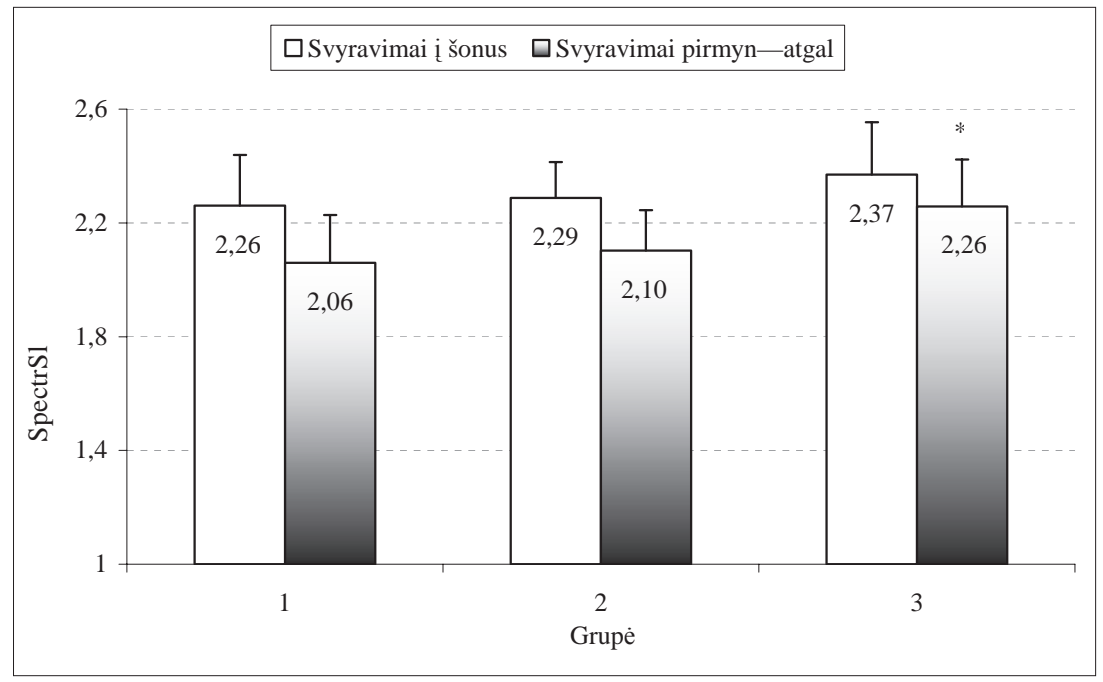

statistiškai reikšmingai mažesnè $(\mathrm{p}<0,01)$ nei pirmos grupès $(0,37)$. SCdy svyravimų SampEn vidutinè reikšmè $(0,34)$ statistiškai reikšmingai mažesnè ir už pirmos $(0,47)(p<01)$, ir už antros grupès $(0,43)(p \leq 0,01)$ SCdy svyravimų SampEn.

Spektrinès analizès duomenys parodè, kad didejant amžiui SCdy svyravimu signalai labiau koncentruojasi žemų dažnių srityje, t. y. lètejja (5 pav.). Trečios grupès tiriamujų SCdy svyravimų SpectrSl vidutinė reikšmė $(2,26)$ statistiškai reikšmingai $(\mathrm{p}<05)$ didesnè nei pirmos $(2,06)$ ir antros $(2,10)$ grupès.

\section{REZULTATŲ APTARIMAS}

Pusiausvyros tyrimo rezultatai patvirtino kitu tyrejjų (Sabatini, 2000; Cavanaugh et al., 2007) gautuosius, teigiančius, kad kūno svyravimu amplitudè ramiai stovint didèja bėgant metams. Vyresnio amžiaus (3 grupės) tiriamujų svyravimu i šonus amplitudè statistiškai patikimai didesnè $(\mathrm{p}<0,05)$ nei jaunesnio amžiaus (1 grupès). Svyravimų pirmyn-atgal amplitudè statistiškai patikimai $(\mathrm{p}<0,05)$ didesnè vyresnio (3 grupès) ir vidutinio (2 grupès) nei jaunesnio (1 grupès) amžiaus tiriamujų. Nustatyta, kad bėgant metams tiriamujų SCdx ir SCdy didejja, t. y. ramiai stovint SC svyravimų amplitudè didejja.

Vertinant pusiausvyros sistemos elgsenos kompleksiškumą nustatyta: vyresnio amžiaus (3 grupès) tiriamujų SC svyravimų i šonus SampEn reikšmė statistiškai reikšmingai mažesnè $(\mathrm{p}<0,01)$ nei jaunesnio amžiaus (1 grupès), SC svyravimu pirmyn—atgal kryptimi SampEn reikšmè - statistiškai reikšmingai mažesnè ( $p<0,01$ ) nei vidutinio (2 grupès) ir jaunesnio (1 grupès) amžiaus tiriamujų. Taigi didejjant amžiui Samp En reikšmė mažejja. Tai rodo tiriamuju SC svyravimų išlaikant pusiausvyrą kompleksiškumo mažèjimą.

Jau vidutinio amžiaus tarpsniu (2 grupejje) pastebimas pusiausvyros elgsenos kompleksišku- 
mo sumažejjimas, tačiau lyginant rodiklius su jaunesnio amžiaus (1 grupès) tiriamųjų šis skirtumas statistiškai nereikšmingas.

Tyrimo rezultatai parodè, kad didejjant amžiui SC svyravimų signalas labiau koncentruojasi žemų dažnių srityje, t. y. pusiausvyros svyravimai lètėja. Vyresnio amžiaus (3 grupès) tiriamujų SC svyravimų pirmyn—atgal SpectrSl reikšmė statistiškai reikšmingai didesnè ( $\mathrm{p} \leq 0,05)$ nei jaunesnio (1 grupès) ir vidutinio (2 grupès) amžiaus tiriamuju. Vidutinio amžiaus (2 grupès) tiriamuju pusiausvyros svyravimai lètesni nei jaunesnio amžiaus (1 grupės), tačiau statistiškai reikšmingo skirtumo neaptikta.

Bet kurio gyvo organizmo atskiru fiziologiniu sistemu funkcijų kaita yra unikali (Goldberger, 2002). Iš sistemos elgsenos vidurkio nereikètu spręsti apie atskirą atveji, o iš atskiro atvejo negalima tiksliai suprasti, kaip elgsis daugelis sistemų. Naujausi mokslo pasiekimai rodo, kad sudètingu dinaminių sistemų elgsenos optimalus kompleksiškumas garantuoja sistemos geresni prisitaikymą iprastomis ir neiprastomis sąlygomis (Prigogine, 1997; Adami, 2002).

\section{IŠVADOS}

Tyrimo rezultatai parodè, kad didejjant amžiui kūno slėgio centro svyravimų trajektorijos kompleksiškumas ramiai stovint mažèja, t. y. svyravimai reguliarèja ir lètėja. Taikant netiesinės dinamikos metodus galima ivvairiapusiškiau ištirti žmonių motorinių sistemų funkcijų kaitą.

\section{LITERATŪRA}

Adami, C. (2002). What is complexity? BioEssays, 24, 1085-1094.

Cavanaugh, J. T., Mercer, V. S., Stergiou, N. (2007). Approximate entropy detects the effect of secondary cognitive task on postural control in healthy young adults; a methodological report. Journal of Neuroengineering and Rehabilitation, 4, 42, 1-7.

Donker, S. F., Roerdink, M., Greven, A. J., Beek, P. J. (2007). Regularity of center of pressure trajectories depends on the amount of attention invested in postural control. Experimental Brain Research, 10, 1-21.

Enoka, R. M., Christou, E. A., Hunter, S. K. et al. (2003). Mechanisms that contribute to differences in motor performance between young and old adults. Journal of Electromyography and Kinesiology, 13, 1-12.

Goldberger, A. L., Amaral, L. A. N., Hansdorff, J. M. et al. (2002). Fractal dynamics in physiology: Alterations with disease and aging. Proceedings of the National Academy of Sciences of the United States of America, 99, 2466-2467.

Hong, S. L., Bodfish, J. W., Newell, K. M. (2006). Power-law scaling for macroscopic entropy and microscopic complexity: Evidence from human movement end posture. Chaos, 16, 2-10.

Juodžbalienè, V. (2006). Klinikiniai ir instrumentiniai pusiausvyros tyrimo metodai. Kineziterapija, 1 (7), 10-13.
Lipsitz, L. A. (2004). Physiological complexity, aging, and the path to frailty. Science of Aging Knowledge Environment, 97, 454-455.

Pincus, S. M. (1991). Approximate entropy as a measure of system complexity. Proceedings of the National Academy of Sciences of the United States of America, 88, 2297-2301.

Prigogine, I. (1997). End of Certainty: Time, Chaos, and New Laws of Nature. Oxford: the Free Press.

Richmann, J. S., Moorman, J. R. (2000). Physiological time series analysis using approximate entropy and sample entropy. American Journal of Physiology. Heart and Circulatory Physiology, 278, H 2039-2049.

Sabatini, A. M. (2000). Analysis of postural sway using entropy measures of signal complexity. Medical and Biological Engineering and Computing, 38, 617-624.

Schultz, A. B. (1992). Mobility impairment in the elderly: Challenges for biomechanics research. Journal of Biomechanics, 5, 519-528.

Vaillancourt, D. E., Newell, K. M. (2003). Aging the time and frequency structure of force output variability. Journal of Applied Physiology, 94, 903-912. 


\title{
EVALUATION OF THE COMPLEXITY OF BALANCE CHANGES IN WOMEN OF DIFFERENT AGE APPLYING THE METHODS OF NONLINEAR DYNAMICS
}

\author{
Vida Janina Česnaitienė, Kazimieras Pukẻnas, Albertas Skurvydas, \\ Dalia Mickevičienė, Tomas Juraitis \\ Lithuanian Academy of Physical Education, Kaunas, Lithuania
}

\begin{abstract}
Due to age and diseases various physiological systems of the human body lose adapted abilities and decrease their stability. However, the human organism has more muscle bulk, neuronal schemes and hormone resources that are necessary for surviving. Those physiological resources allow maintaining balance in the process of aging and diseases (Lipsitz, 2004). Balance, which is one of the physiological systems, disorders are determined by testing the subjects applying functional tests or instrumental research methods of balance (Juodžbalienè, 2006). One of the mort often applied methods of the evaluation of balance is static posturography. The evaluation of balance changes applying methods of nonlinear dynamics allows establishing its complexity (Pincus, 1991).

The aim of the study was to analyze the impact of age on the complexity of balance changes applying methods of nonlinear dynamics. For this aim we studied 45 women of different age groups (mean age: $24.5 \pm 5.5$; $44.5 \pm 3.5 ; 72.5 \pm 7.5$ years) applying the instrumental method of balance research - method of posturography. The subjects stood restfully on the power plate, and we registered the swings of their body pressure centers (PC) to the sides, and backwards and forwards. The complexity of balance changes was evaluated estimating its two characteristics - Sample Entrophy (SampEn) and Spectral Slope.

Research results indicated that the amplitude of body swings standing in the restful position increased with the increase of age. The amplitude of wings to the sides and backwards and forwards of older women was statistically significantly higher compared to younger women $(p<0.05)$. Evaluating the complexity of balance system behavior we established that the Samp En value of PC swings to the sides of older women was statistically significantly greater than that of younger women $(\mathrm{p}<0.01)$. We established that the Spectral Slope value of PC swings backwards and forwards of older women was statistically significantly higher compared to younger and middle-aged women $(\mathrm{p}<0.05)$.

Research results showed that the complexity of balance changes became more regular with age, and PC body swings to the sides, backwards and forwards standing in the restful position became slower. The application of methods of nonlinear dynamics enables a more comprehensive study of the dynamics of functions of human motor systems.
\end{abstract}

Keywords: age, balance, regularity, complexity.

Gauta 2008 m. balandžio 21 d.

Received on April 21, 2008

Vida Janina Česnaitienè Lietuvos kūno kultūros akademija (Lithuanian Academy of Physical Education) Sporto g. 6, LT-44221 Kaunas

Lietuva (Lithuania)

Tel +370 37302642

E-mail v.cesnaitiene@lkka.lt 